Marquette University

e-Publications@Marquette

College of Education Faculty Research and

Publications

Education, College of

$10-1-2004$

\title{
Assessing Student Exposure to and Use of Computer Technologies through an Examination of Course Syllabi
}

\author{
Michael B. Madson \\ Marquette University \\ Timothy P. Melchert \\ Marquette University, timothy.melchert@marquette.edu \\ Joan Whipp \\ Marquette University, joan.whipp@marquette.edu
}

Published version. Assessment and Evaluation in Higher Education, Vol. 29, No. 5 (October 2004): 549-561. DOI. (C) 2004 Taylor \& Francis. Used with permission. 


\title{
Assessing Student Exposure To and Use of Computer Technologies through an Examination of Course Syllabi
}

\author{
Michael B. Madson \\ Marquette University \\ Milwaukee, WI \\ Timothy P. Melchert \\ Department of Counseling and Education Psychology, Marquette \\ University \\ Milwaukee, WI \\ Joan L. Whipp \\ Department of Educational Policy and Leadership \\ Marquette University \\ Milwaukee, WI
}

\begin{abstract}
A syllabus analysis instrument was developed to assist program evaluators, administrators and faculty in the identification of skills that students use as they complete their college coursework. While this instrument can be tailored for use with a variety of learning domains, we used it to assess students' use of and exposure to computer technology skills. The reliability and validity of the instrument was examined through an analysis of 88 syllabi from courses within the teacher education program and the core curriculum at a private Midwest US university. Results indicate that the instrument has good inter-rater reliability and ratings by and interviews with

Assessment and Evaluation in Higher Education, Vol. 29, No. 5 (2004): pg. 549-561. DOI. This article is (C) Taylor \& Francis (Routledge) and permission has been granted for this version to appear in e-Publications@Marquette. Taylor \& Francis (Routledge) does not grant permission for this article to be further copied/distributed or hosted elsewhere without the express permission from Taylor \& Francis (Routledge).
\end{abstract}


NOT THE PUBLISHED VERSION; this is the author's final, peer-reviewed manuscript. The published version may be accessed by following the link in the citation at the bottom of the page.

faculty and students provide evidence of construct validity. The use and limitations of the instrument in educational program evaluation are discussed.

\section{Introduction}

Educational program evaluation has become more important in recent years as a result of regional and professional accrediting bodies requiring that institutions have effective evaluation processes to assess student achievement and engage in systematic and comprehensive self-study (see, for example, North Central Association of Colleges and Schools Commission on Higher education, 1997). While course syllabi themselves do not provide outcome data regarding the achievement of program goals and objectives, they generally do document the learning activities and assessments that comprise a curriculum. They also provide a framework for using evaluation feedback to make program modifications and improvements at the course level. Consequently, accreditation reviews are placing much more attention on syllabi organizing the objectives and assessment activities of courses within academic programs. In fact, the majority of higher education accreditation self-studies are probably specifically organized around the evaluation of individual courses (Nichols \& Nichols, 2001).

Recently, the teacher education program at our university was redesigned to increase the emphasis on computer technology skills at the same time that it was preparing for a major accreditation review. To help assess the extent of changes in the program since the redesign, we wanted to examine which technology skills students were using as they completed their coursework. A search of the literature, however, found no systematic, psychometrically sound approach for collecting information about courses and their contribution to a curriculum. Eberly et al. (2001) presented a framework for analyzing course syllabi, but their model broadly examines the content of syllabi and cannot be easily applied to the analysis of a particular set of skills. They also did not examine the psychometric properties of their instrument. Therefore, we developed a syllabus analysis instrument that can be used to help identify the skills that students are exposed to and expected to demonstrate during the completion of course assignments. Before describing the development of this instrument, we will discuss the role of syllabi in higher education. We will then provide the context for our application of the instrument to examine students' exposure to and use of computer technology skills.

Assessment and Evaluation in Higher Education, Vol. 29, No. 5 (2004): pg. 549-561. DOI. This article is (C) Taylor \& Francis (Routledge) and permission has been granted for this version to appear in e-Publications@Marquette. Taylor \& Francis (Routledge) does not grant permission for this article to be further copied/distributed or hosted elsewhere without the express permission from Taylor \& Francis (Routledge). 


\section{Course syllabuses in higher education}

The course syllabus is an essential tool for communication between the instructor and student in higher education. The main purpose of the syllabus is to communicate the intent, direction and expectations for a course (Birdsall, 1989; Altman \& Cashin, 1992; Johnson, 1995; Wankat, 2002). For students, the syllabus provides critical information for making decisions on issues like whether to remain in a course, how to prioritize the workload and how to be successful in a class. Research indicates that college students, both traditional and non-traditional, learn more effectively when they understand faculty expectations for courses (Lowther et al., 1989). By providing clear information regarding their expectations, instructors can reduce student anxiety, reinforce positive attitudes and enhance students' ability to learn and perform well. Providing accurate and comprehensive course information also suggests that instructors are well prepared, which may increase student confidence in the instructors and facilitate student learning in the course (Grunnert, 1997).

In addition, the syllabus is often viewed as an informal contract between instructors and their students (Brodeur, 1986; Lowther et al., 1989), while others view it as a binding document for purposes of evaluation and grading (Altman, 1989; Dixon, 1991). Consequently, students can use the syllabus to address legal disagreements about their performance in a course (Hollander et al., 1985). Likewise, instructors can use the syllabus to document that a student was appropriately evaluated when there is a disagreement about a grade assigned in a course. For example, in the case of Hill versus University of Kentucky, the student's legal challenge over his expulsion after failing a course was dismissed in part because the instructor was found to have followed the guidelines of the syllabus in the grading of the student (Parkes \& Harris, 2002).

Handelsman et al. (1987) used the principles of informed consent from the healthcare field to suggest that ethical educational practice requires instructors to provide clear information to students so they can make informed decisions about their courses. They suggest that the syllabus must address three areas to allow such informed choice: course subject matter (the course description); course expectations (objectives); course evaluation procedures (major assignments, grading policies). This allows students to make informed

Assessment and Evaluation in Higher Education, Vol. 29, No. 5 (2004): pg. 549-561. DOI. This article is (C) Taylor \& Francis (Routledge) and permission has been granted for this version to appear in e-Publications@Marquette. Taylor \& Francis (Routledge) does not grant permission for this article to be further copied/distributed or hosted elsewhere without the express permission from Taylor \& Francis (Routledge). 
choices about courses, much like patients make choices about particular surgical procedures or treatment alternatives. Consequently, syllabi need to be as accurate and specific as possible in order to reduce ambiguity and the idiosyncratic interpretation of course requirements and expectations (Vattano, 1987; Birdsall, 1989; Ryan \& Martens 1989; Serafin, 1990). In fact, the recent revision of the American Psychological Association's (2002) 'Ethical principles of psychologists and code of conduct' directly addresses this issue. Specifically, Code 7.03 regarding accuracy in teaching states:

Psychologists take reasonable steps to ensure that course syllabi are accurate regarding the subject matter to be covered, bases for evaluating progress, and the nature of course experiences. This standard does not preclude an instructor from modifying course content or requirements when the instructor considers it pedagogically necessary or desirable, so long as students are made aware of these modifications in a manner that enables them to fulfill course requirements. (p. 10)

One of the three areas identified by Handelsman et al. (1987) that syllabi must address to allow informed decisions by students is the course description. This part of a syllabus helps orient students to a course, creates interest and enhances motivation to learn the subject (Birdsall, 1989). It can also help clarify the relationship of the course to the students' academic development, program goals, general education requirements and the institutional mission (Lowther et al., 1989; Parkes \& Harris, 2002). The second section of a syllabus needed to allow informed consent by students concerns the course objectives, which communicate expectations regarding the knowledge and skills that will be learned, serve as an instructional guide, provide structure for the course and assure proper evaluation procedures (Broduer, 1989). Unclear course objectives can result in student complaints regarding unfair tests or assignments, course disorganization and lack of fit between topics. The activities section of the syllabus is critical because it communicates the academic workload that students will be responsible for in a course. Descriptions of activities help students understand how they will be evaluated and what they need to do to complete courses successfully. Lowther et al. (1989) found that students often report that instructors do not clearly describe either the connection of particular activities to course objectives or the

Assessment and Evaluation in Higher Education, Vol. 29, No. 5 (2004): pg. 549-561. DOI. This article is (C) Taylor \& Francis (Routledge) and permission has been granted for this version to appear in e-Publications@Marquette. Taylor \& Francis (Routledge) does not grant permission for this article to be further copied/distributed or hosted elsewhere without the express permission from Taylor \& Francis (Routledge). 
expectations of those activities, a complaint which can be easily avoided by a careful and thorough approach to writing syllabi.

\section{Examining syllabi to assess use of technology in a teacher education program}

The teacher education faculty at our university recently decided to revise the curriculum to ensure that our students would enter their careers with the ability to effectively utilize a range of computer technologies in their future teaching. Many practicing teachers limit their use of computer technology to video presentations, word processing and basic skills practice programs, while more advanced technologies, such as desktop publishing, video conferencing and electronic discussions, have greater potential to increase engagement and achievement among students (Milken Exchange on Educational Technology, 1999; Tharp et al., 2000). Consequently, our teacher education curriculum was revised to ensure that students learn about a range of technologies useful for student learning.

To provide both formative and summative evaluation data to the faculty, we needed an instrument that would estimate students' exposure to and use of various technology skills in the existing curriculum, as well as measure the extent of change in this area of the curriculum after the program redesign. Due to resource limitations, we also needed an instrument that was highly efficient and easy to use. We designed our measure to be used with any identified domain of learning within higher education curricula, although we focused on technology skills in our initial application of the instrument. We based our examination of technology skills on the National Educational Technology Standards developed by the International Society for Technology in Education (ISTE) (2000). These standards are used to prepare teachers who can demonstrate a sound understanding of not only the basic functions of computer technology, but are able to use content-specific tools that support learning and facilitate higher order thinking, collaboration and real world learning. 
NOT THE PUBLISHED VERSION; this is the author's final, peer-reviewed manuscript. The published version may be accessed by following the link in the citation at the bottom of the page.

\section{Method}

\section{Syllabi and Participants}

We analyzed 88 syllabi from the required courses within the teacher education program at our university as well as the courses that our teacher education students normally take to meet their general education requirements. The 41 syllabi we examined from the teacher education program were taught by 14 different faculty members, while the 47 syllabi from the general education curriculum were taught by 24 different faculty from the College of Arts and Sciences and the College of Communication.

Two groups of faculty and one group of students were included in our examination of the validity of the information obtained with the instrument. A group of eight faculty from the teacher education program ( 7 female and 1 male with a mean of 9.01 years of teaching experience) were asked to rate the accuracy of 11 syllabi for courses they had taught the previous semester. There were also 22 faculty from the College of Arts and Sciences and College of Communication ( 9 females and 13 males with a mean of 21.09 years of teaching experience) who were interviewed about the integration of technology into their courses and the accuracy of their syllabi. We also surveyed 64 teacher education students about the accuracy of the syllabus for one of the courses they took the previous semester. These students ranged from freshman to juniors in terms of class standing.

\section{Instrument}

The Syllabus Assessment Instrument (SAI) developed for this study was designed to assess exposure to and use of skills in a specific domain of learning within courses in a higher education curriculum. The instrument focuses on the three components of a course syllabus identified by Handelsman et al. (1987): the course description, course objectives and course activities. In the first section of the instrument, raters are asked to determine whether exposure to a set of targeted skills (in this case, technological skills) is 'explicitly', 'implicitly' or 'not at all' stated in the course description and each of the course objectives. Raters were instructed to categorize a course description or objective as explicit with regard to the use of technology if it contained statements such as 'A goal of this course is for students to become knowledgeable of the possibilities for using computer technology in 
teaching'. Raters were instructed to categorize a course description or objective as 'implicit' with regard to the use of computer technology if it referred to a broad array of topics that was likely to include the subject of computer technologies (e.g. 'A goal of this course is to introduce students to a variety of educational methods and techniques'), because we had found that courses which included such statements did include technology among the topics covered even though this was not explicitly indicated on the syllabus.

The second section of the instrument asks raters to identify whether a targeted set of skills is needed to be able to complete each of the course activities successfully and, if so, to identify which particular skills are needed based on a list developed to represent the domain of skills that has been targeted. For this study, we developed a list of technology skills based on the ISTE (2000) National educational technology: standards for teachers. The importance given to the development of each of these various skills is then estimated by noting the proportion of the total course points that is given to the assignments that require the use of the identified skills. A copy of the instrument is available from the study authors.

\section{Procedure}

The reliability of the SAI was examined by calculating the level of agreement between two raters who independently used the instrument to rate the study syllabi. The validity of the information obtained with the SAI was examined through the use of three procedures. First, we asked 8 faculty members to use a scale ranging from 1 ('not at all') to 4 ('completely') to respond to the following questions: (i) how accurate is the course description that appears on your syllabus in describing the general purposes and nature of the course; (ii) how well were the objectives, as they appear on the course syllabus, accomplished in the course? We then asked these faculty if computer technology was required for each activity in the course and, if so, to identify which technology skills were needed to successfully complete the class activities. Second, we asked the same questions of 64 students who had taken one of four courses for which we analyzed the syllabus (the number of students per class ranged from 12 to 21). Finally, interviews were conducted with 22 faculty members regarding their integration of computer technology into their courses. These faculty were not asked to make specific ratings regarding the accuracy

Assessment and Evaluation in Higher Education, Vol. 29, No. 5 (2004): pg. 549-561. DOI. This article is (C) Taylor \& Francis (Routledge) and permission has been granted for this version to appear in e-Publications@Marquette. Taylor \& Francis (Routledge) does not grant permission for this article to be further copied/distributed or hosted elsewhere without the express permission from Taylor \& Francis (Routledge). 
of their syllabus, but were asked to explain the accuracy of their syllabi in describing their integration of technology into their courses.

\section{Results}

\section{Reliability}

The independent ratings of the description, objectives and assignments for the 68 study syllabi resulted in very high levels of agreement. Cohen's $\mathrm{K}$ for the inter-rater agreement for the course descriptions was 1.00, while the level of agreement for the course objectives was 0.91 . The level of agreement with regard to the computer technology skills required to complete course assignments successfully was 0.88 . The raters then discussed disagreements until they arrived at a consensus regarding the most accurate ratings. Most of the disagreements involved clerical errors by the raters or categorizing a course objective as having 'no statement' regarding the use of computer technology rather than having an 'implicit' statement.

\section{Validity}

We first asked 8 teacher education faculty to rate the accuracy of their syllabi in describing 11 different courses they had taught the previous semester. On a scale ranging from 1 ('not at all accurate') to 5 ('completely accurate'), the faculty indicated that the course description was 'completely accurate' for seven of the courses and 'mostly accurate' for the four remaining courses. Of the 90 objectives analyzed across the 11 courses, the faculty indicated that $41 \%$ were met 'completely' and 46\% 'satisfactorily', but they also indicated that $13 \%$ were met only 'minimally'. Regarding the particular computer technology skills that were needed to complete the coursework successfully, there was $78 \%$ agreement between the identifications made by the instructors and the researchers.

A second set of 22 faculty who taught core general education courses were also asked to explain the accuracy of their syllabi in describing their courses. Two of these faculty (9\%) stated that their syllabi did not accurately reflect the use of technology in their courses and that they actually emphasized technology more than what their syllabi indicated.

We also asked students to rate the accuracy of four syllabi using the same 4 point scales used with the teacher education faculty. 
Across the four courses, 55\% of the students reported that the course description was 'completely accurate', 37\% reported that the description was 'mostly accurate', while $8 \%$ indicated that the course description was only 'somewhat accurate'. In the first class, students indicated that the objectives were met 'completely' (79\%), 'satisfactorily' (19\%) or 'minimally' $(2 \%)$. In the second class, students indicated that the objectives were either met 'completely' (40\%), 'satisfactorily' (40\%), 'minimally' (14\%) or 'not at all' (6\%). Students from the third class rated the objectives as having been met 'completely' (35\%), 'satisfactorily' (42\%), 'minimally' $(22 \%)$ or 'not at all' $(1 \%)$. The objectives in the fourth class were rated as having been met 'completely' (75\%), 'satisfactorily' (24\%) or 'minimally' (1\%).

The primary assignment for the first course included the development of a portfolio. There was $100 \%$ agreement among the students that this assignment required the use of technology, but the specific types of technology skills that needed to be used could not be identified because students were allowed to choose the types of technologies they included in their portfolio. Across the assignments in the second class, and there was 78\% agreement between the students and the raters that technology had to be used to complete the assignments successfully, it was again unclear which types of technology needed to be used to successfully complete the assignments. In the third class, there was 100\% agreement between the raters and the students regarding the need to use six specific technology skills, 75-99\% agreement regarding the use of five other specific skills, $50-74 \%$ agreement regarding the use of five other skills and $49 \%$ or less agreement regarding the use of seven other skills. In the fourth class, there was 100\% agreement between the raters and the students regarding the need to use one specific skill, 75-99\% agreement regarding the use of four other specific skills, 50-74\% agreement regarding the use of two other skills and $49 \%$ or less agreement regarding the use of seven other skills. Across these courses, the most frequent disagreements between the raters and the students concerned the necessity of using the World Wide Web or database searches to complete particular assignments successfully. Follow-up conversations with the students found that professors' verbal instructions or class handouts indicated that use of these technologies was needed to complete the assignments successfully, even though it was not indicated on the syllabus.

Assessment and Evaluation in Higher Education, Vol. 29, No. 5 (2004): pg. 549-561. DOI. This article is (C) Taylor \& Francis (Routledge) and permission has been granted for this version to appear in e-Publications@Marquette. Taylor \& Francis (Routledge) does not grant permission for this article to be further copied/distributed or hosted elsewhere without the express permission from Taylor \& Francis (Routledge). 


\section{Emphasis on technology in the curriculum}

Examination of the course syllabi from the original 1998-2001 curriculum found that 8 of the 68 syllabi (12\%) included explicit statements regarding the use of computer technology in their course descriptions and none analyzed included implicit references to technology in the description. With regard to the course objectives, 17 of the 68 syllabi (25\%) included explicit statements about the use of technology, while another $7(10 \%)$ included implicit references to technology use. Taken together, 25 (37\%) of the 68 syllabi included either explicit or implicit statements regarding the use of technology in either the course description or objectives.

Relatively few of the activities assigned in these courses, however, required the use of technology skills. Table 1 indicates the number of courses that required the use of specific technology skills in order to successfully complete the various assignments across the 68 courses in the 1998-2001 curriculum. The weight given to the assignments that required the use of technology skills (i.e. the points given to these assignments compared with the total points possible in each class) was also low. In fact, the grand mean across all of the 19 skill categories for all 68 courses analyzed was $3.2 \%$ (i.e. only $3.2 \%$ of the total course points across all 68 of the courses was given to assignments that required the use of computer skills).

As a result of the relatively low emphasis given to the development of technology skills in the 1998-2001 curriculum, the faculty in the teacher education program redesigned several courses to increase the learning of these skills. Faculty who were not well versed in these skills were provided training and/or consultative support so that they could integrate a variety of technologies into their class presentations and assignments. Both technical and instructional support were offered, depending on the needs of the faculty member involved. To assess the effect of these changes, we compared the emphasis on technology within the 21 courses in the 1998-2001 teacher education program to the technology emphasis in the 20 courses in the 2002-2003 program after it was redesigned. Before the curriculum redesign, only 4 of the 21 courses included an explicit reference to technology within the course descriptions or objectives and no additional syllabi included implicit references to technology. After the redesign, however, 10 of the 20 courses included an explicit

Assessment and Evaluation in Higher Education, Vol. 29, No. 5 (2004): pg. 549-561. DOI. This article is (C) Taylor \& Francis (Routledge) and permission has been granted for this version to appear in e-Publications@Marquette. Taylor \& Francis (Routledge) does not grant permission for this article to be further copied/distributed or hosted elsewhere without the express permission from Taylor \& Francis (Routledge). 
reference to technology within the course descriptions or objectives and another 7 included implicit references to technology.

There was also a substantial increase in the number of courses that required the use of technology skills in order to complete the course activities. In the 1998-2001 curriculum, 8 of the 21 courses required the use of at least one technology skill in order to complete the course activities successfully and 5 required the use of technology skills besides word processing and the Internet. After the redesign, 16 of the 20 courses required the use of at least one type of technology in the course activities and 9 required the use of technology skills besides basic word processing and the Internet. Indeed, there was one course that now required the use of technology for each of its assignments (i.e. $100 \%$ of that course grade was dependent on using technology). Of the total number of points given across the 21 courses in the 19982001 curriculum, only $1.5 \%$ were given to assignments that required the use of one or more technology skills. Of the total number of course points given in the redesigned curriculum, however, $36.7 \%$ was given to assignments that required the use of technology skills.

The particular technology skills that were needed to complete the courses in the old compared with the redesigned curriculum are indicated in Table 1. Word processing and use of the Internet are the most often required uses of technology across these courses, but there was a clear movement toward requiring the use of other technologies after the curriculum was redesigned as well.

\section{Discussion and Implications}

In addition to documenting the purpose, direction, expectations and grading for higher education courses, syllabi provide useful information for evaluation purposes because they often describe the knowledge and skills that will be acquired through successful completion of the course activities. Therefore, we developed an instrument to examine the syllabi for the courses completed by students in the teacher education program at our university in order to assess their exposure to computer technology and the technology skills they would need to use to complete the course activities successfully.

The results of the study suggest that the data obtained with the SAI are quite reliable and reasonably valid. We found very high interrater agreement between the two raters who independently analyzed

Assessment and Evaluation in Higher Education, Vol. 29, No. 5 (2004): pg. 549-561. DOI. This article is (C) Taylor \& Francis (Routledge) and permission has been granted for this version to appear in e-Publications@Marquette. Taylor \& Francis (Routledge) does not grant permission for this article to be further copied/distributed or hosted elsewhere without the express permission from Taylor \& Francis (Routledge). 
course syllabi, although the results regarding the accuracy of the syllabi in describing the courses were more variable. The primary reason for this was that several syllabi did not thoroughly describe the nature or expectations of particular courses. Consequently, the teacher education program administrators overhauled the process of developing syllabi in the program. They developed a template for writing syllabi and worked with instructors to ensure that syllabi accurately described how individual courses contributed to achieving the overall program standards. Consequently, the syllabus analysis proved quite useful for formative evaluation purposes. Indeed, the redesign of our teacher education program has been thorough and a variety of stakeholders have been pleased with the results to date. The program is also in a far better position to enter its upcoming reaccreditation review as a result of this process.

There are several limitations, however, to the use of syllabi to assess skills that are developed in a higher education curriculum. Thoroughly evaluating a curriculum is obviously a complex undertaking and syllabi provide only limited data with which to assess the knowledge, skills and dispositions that students develop as they complete a program. Developing reliable measures of course outcomes (i.e. the knowledge, skills and dispositions that students acquire through completion of a course) is quite an ambitious undertaking and administering these measures before and after students take courses to assess their learning would involve a significant investment of resources. Undertaking a process evaluation of courses to assess how teaching and learning were taking place would also require substantial resources to observe class meetings as well as assess what students do outside class as they study the course content and work on class activities. These more thorough evaluations would obviously provide more complete data about the skills that students develop through completion of their courses, while the assessment of syllabi described above provides only global estimates of course processes and outcomes and really focuses on students' use of and exposure to a set of skills rather than their skill development per se. Perhaps the primary advantage of conducting an examination of syllabi is its efficiency in that syllabi provide an immediately available source of information to examine the role courses play in advancing the objectives of a program. Using syllabi for this purpose obviously becomes much more challenging, however, when they are not

Assessment and Evaluation in Higher Education, Vol. 29, No. 5 (2004): pg. 549-561. DOI. This article is (C) Taylor \& Francis (Routledge) and permission has been granted for this version to appear in e-Publications@Marquette. Taylor \& Francis (Routledge) does not grant permission for this article to be further copied/distributed or hosted elsewhere without the express permission from Taylor \& Francis (Routledge). 
thorough or accurate. Inaccurate syllabi can also give rise to student complaints, dissatisfaction and even legal challenges, as well as make the process of program accreditation review more complicated.

The SAI can be used to assess students' exposure to a domain of learning and their use of skills related to that domain for perhaps any area of learning in higher education. We, of course, focused on computer technology skills using the widely accepted set of technology standards developed by ISTE (2000). To use the instrument for other learning domains, two adaptations would need to be made. First, decision rules should be developed regarding the distinction between explicit and implicit references to the learning domain of interest. Second, the set of skills represented in that domain of learning need to be identified. Relying on a previously developed and widely accepted list of skills for a particular learning domain will make the task of converting the measure for use in that area easier and can also enhance the content validity of the measure.

With the growing emphasis on accountability and outcomes in higher education, educational program evaluation has quickly become more important. Thoroughly evaluating educational curricula involves a great deal more than just an examination of course syllabi, but when one needs an efficient assessment of how sets of skills are developed within a curriculum, the SAI can provide useful information with which to guide program development and improvement through evaluation.

\section{Notes on Contributors}

Michael Madson is a doctoral candidate in counseling psychology at Marquette University in Milwaukee, Wisconsin, USA. He received his Master of Science in Education from the University of Wisconsin-Superior in Guidance and Counseling. His research interests include the training and supervision of psychologists, measurement and program evaluation.

Timothy Melchert is associate professor and chair of the Department of Counseling and Educational Psychology at Marquette University. His research interests include program evaluation and measurement, as well as the influences of parenting and child maltreatment.

Joan Whipp is assistant professor and co-chair of the Department of Educational Policy and Leadership at Marquette University. Her research interests include pedagogical uses of instructional technology and web-based teaching and learning.

Assessment and Evaluation in Higher Education, Vol. 29, No. 5 (2004): pg. 549-561. DOI. This article is (C) Taylor \& Francis (Routledge) and permission has been granted for this version to appear in e-Publications@Marquette. Taylor \& Francis (Routledge) does not grant permission for this article to be further copied/distributed or hosted elsewhere without the express permission from Taylor \& Francis (Routledge). 
NOT THE PUBLISHED VERSION; this is the author's final, peer-reviewed manuscript. The published version may be accessed by following the link in the citation at the bottom of the page.

\section{References}

Altman, H. B. (1989) Syllabus shares what 'what the teacher wants', The Teaching Professor, 3, 1-2.

Altman, H. B. \& Cashin, W. E. (1992) Writing a syllabus, Idea Paper (Manhattan, KS, Center for Faculty Education and Development) (Eric Document Reproduction Service No. 395 539).

American Psychological Association (2002) Ethical principles of psychologists and code of conduct, American Psychologist, 57, 1060-1073.

Birdsall, M. (1989) Writing, designing, and using a course syllabus (Boston, MA, Northeastern University Office for the Support of Effective Teaching).

Broduer, D. R. (1986) What does your syllabus communicate? (Normal, IL, Illinois State University) (Eric Document Reproduction Service No. 268 911).

Dixon, T. P. (1991) A brief review of literature concerning syllabi, a colloquium concerning syllabuses sponsored by the University of Central Texas (Eric Document Reproduction Service No. 330278).

Eberly, M. B., Newton, S. E. \& Wiggins, R. A. (2001) The syllabus as a tool for student-centered learning, The Journal of General Education, 50, 5674.

Grunnert, J. (1997) The course syllabus: a learning-centered approach (Bolton, MA, Anker Publishing Co.).

Handelsman, M. M., Rosen, J. \& Arguello, A. (1987) Informed consent of students: how much information is enough, Teaching of Psychology, 12, 107-109.

Hollander, P. A., Young, D. P. \& Gerhing, D. D. (1985) A practical guide to legal issues affecting college teachers (Asheville, NC, College Administration Publications).

International Society for Technology in Education (2000) National educational technology: standards for teachers (Eugene, OR, International Society for Technology in Education).

Johnson, G. R. (1995) First steps to excellence in college teaching (Madison, WI, Magna Publications).

Lowther, M. A., Stark, J. S. \& Martens, G. G. (1989) Preparing course syllabi for improved communication (Ann Arbor, MI, National Center for Research to Improve Post Secondary Teaching and Learning) (Eric Document Reproduction Service No. 314 997).

Milken Exchange on Educational Technology (1999) Will new teachers be prepared to teach in a digital age? A national survey on information technology in teacher education (Santa Monica, CA, Milken Exchange on Educational Technology).

Assessment and Evaluation in Higher Education, Vol. 29, No. 5 (2004): pg. 549-561. DOI. This article is (C) Taylor \& Francis (Routledge) and permission has been granted for this version to appear in e-Publications@Marquette. Taylor \& Francis (Routledge) does not grant permission for this article to be further copied/distributed or hosted elsewhere without the express permission from Taylor \& Francis (Routledge). 
NOT THE PUBLISHED VERSION; this is the author's final, peer-reviewed manuscript. The published version may be accessed by following the link in the citation at the bottom of the page.

Nichols, J. O. \& Nichols, K. W. (2001) General education assessment for improvement of student academic achievement: guidance for academic departments and committees (New York, Agathon Press).

North Central Association of Colleges and Schools Commission on Higher Education (1996) Handbook of accreditation (2nd edn) (Chicago, IL, North Central Association of Colleges and Schools).

Parkes, J. \& Harris, M. B. (2002) The purpose of a syllabus, College Teaching, 50, 55-62.

Ryan, M. P. \& Martens, G. G. (1989) Planning a college course: a guidebook for the graduate teaching assistant (Ann Arbor, MI, National Center for Research to Improve Post Secondary Teaching and Learning) (Eric Document Reproduction Service No. 314 998).

Serafin, A. G. (1990) Syllabi and their effects on students' final grade performance (Eric Document Reproduction Service No. 328 202).

Tharp, R. G., Estrada, P., Dalton, S. S. \& Yamauchi, L. A. (2000) Teaching transformed: achieving excellence, fairness, inclusion, and harmony (Boulder, CO, Westview Press).

Vattano, F. (1987) The teaching assistant handbook (Ft Collins, CO, Colorado State University).

Wankat, P. C. (2002) The effective, efficient professor: teaching, scholarship, and service (Boston, MA, Allyn \& Bacon).

Assessment and Evaluation in Higher Education, Vol. 29, No. 5 (2004): pg. 549-561. DOI. This article is (c) Taylor \& Francis (Routledge) and permission has been granted for this version to appear in e-Publications@Marquette. Taylor \& Francis (Routledge) does not grant permission for this article to be further copied/distributed or hosted elsewhere without the express permission from Taylor \& Francis (Routledge). 
NOT THE PUBLISHED VERSION; this is the author's final, peer-reviewed manuscript. The published version may be accessed by following the link in the citation at the bottom of the page.

\section{Appendix}

\section{Table 1: Computer skills needed to successfully complete the course} requirements

\begin{tabular}{|c|c|c|c|c|c|c|}
\hline \multirow[b]{2}{*}{$\begin{array}{l}\text { Computer } \\
\text { technology } \\
\text { skills }\end{array}$} & \multicolumn{2}{|c|}{$1998-2001$ all syllabi } & \multicolumn{2}{|c|}{$\begin{array}{c}1998-2001 \text { education } \\
\text { syllabi }\end{array}$} & \multicolumn{2}{|c|}{$\begin{array}{c}\text { 2002-2003 education } \\
\text { syllabi }\end{array}$} \\
\hline & $\begin{array}{l}\text { Courses } \\
\text { requiring } \\
\text { use of this } \\
\text { skill } n(\%)\end{array}$ & $\begin{array}{l}\text { Grade } \\
\text { requiring } \\
\text { use of } \\
\text { this } \\
\text { skill }(\%)\end{array}$ & $\begin{array}{c}\text { Course } \\
\text { requiring } \\
\text { use of this } \\
\text { skill } n(\%)\end{array}$ & $\begin{array}{l}\text { Grade } \\
\text { requiring } \\
\text { use of } \\
\text { this } \\
\text { skill }^{2}(\%)\end{array}$ & $\begin{array}{l}\text { Courses } \\
\text { requiring } \\
\text { use of this } \\
\text { skill } n(\%)\end{array}$ & $\begin{array}{c}\text { Grade } \\
\text { requiring } \\
\text { use of } \\
\text { this skill } \\
(\%)\end{array}$ \\
\hline $\begin{array}{l}\text { Basic word } \\
\text { processing }\end{array}$ & $16(23.5 \%)$ & $7.8 \%$ & $5(23.8 \%)$ & $16.2 \%$ & $10(50.0 \%)$ & $18.7 \%$ \\
\hline $\begin{array}{l}\text { Complex work } \\
\text { processing (e.g. } \\
\text { including graphics } \\
\text { in text) }\end{array}$ & 0 & 0 & 0 & 0 & 0 & 0 \\
\hline $\begin{array}{l}\text { Using the World } \\
\text { Wide Web }\end{array}$ & $12(17.6 \%)$ & $3.5 \%$ & $5(23.8 \%)$ & $2.9 \%$ & $8(40.0 \%)$ & $10.0 \%$ \\
\hline $\begin{array}{l}\text { Database } \\
\text { Searches (e.g. } \\
\text { ERIC, Psychinfo) }\end{array}$ & 0 & 0 & 0 & 0 & 0 & 0 \\
\hline $\begin{array}{l}\text { Asynchronous } \\
\text { communication } \\
\text { (e.g. email, } \\
\text { discussion board) }\end{array}$ & $3(4,4 \%)$ & $0.7 \%$ & $5(23.8 \%)$ & $3.0 \%$ & $3(15.0 \%)$ & $1.7 \%$ \\
\hline $\begin{array}{l}\text { Synchronous } \\
\text { communication } \\
\text { (e.g. live } \\
\text { discussion room) }\end{array}$ & 0 & 0 & 0 & 0 & 0 & 0 \\
\hline $\begin{array}{l}\text { Downloading and } \\
\text { reading files in a } \\
\text { specific format } \\
\text { (e.g. adobe } \\
\text { Acrobat) }\end{array}$ & 0 & 0 & 0 & 0 & 0 & 0 \\
\hline
\end{tabular}

Assessment and Evaluation in Higher Education, Vol. 29, No. 5 (2004): pg. 549-561. DOI. This article is (C) Taylor \& Francis (Routledge) and permission has been granted for this version to appear in e-Publications@Marquette. Taylor \& Francis (Routledge) does not grant permission for this article to be further copied/distributed or hosted elsewhere without the express permission from Taylor \& Francis (Routledge). 
NOT THE PUBLISHED VERSION; this is the author's final, peer-reviewed manuscript. The published version may be accessed by following the link in the citation at the bottom of the page.

\begin{tabular}{|c|c|c|c|c|c|c|}
\hline $\begin{array}{l}\text { Creating a basic } \\
\text { web page }\end{array}$ & $2(2.9 \%)$ & $0.3 \%$ & 0 & 0 & 0 & c \\
\hline $\begin{array}{l}\text { Creating a } \\
\text { complex web } \\
\text { page with more } \\
\text { advanced } \\
\text { features (forms, } \\
\text { frames, } \\
\text { navigation. } \\
\text { scripts, } \\
\text { animation) }\end{array}$ & 0 & 0 & 0 & 0 & $1(5.0 \%)$ & $1.0 \%$ \\
\hline $\begin{array}{l}\text { Present a simple } \\
\text { PowerPoint } \\
\text { presentation (text } \\
\text { only) }\end{array}$ & $1(1.5 \%)$ & $2.5 \%$ & $1(4.8 \%)$ & $1.7 \%$ & $1(5.0 \%)$ & $3.5 \%$ \\
\hline $\begin{array}{l}\text { Present an } \\
\text { advanced } \\
\text { PowerPoint } \\
\text { presentation } \\
\text { (integrating media } \\
\text { clips, audio, } \\
\text { pictures) }\end{array}$ & 0 & 0 & 0 & 0 & $1(5.0 \%)$ & $5.5 \%$ \\
\hline $\begin{array}{l}\text { Using a database } \\
\text { (e.g, Excel, } \\
\text { Access) }\end{array}$ & 0 & 0 & 0 & 0 & $1(5.0 \%)$ & $1.0 \%$ \\
\hline $\begin{array}{l}\text { Developing } \\
\text { multimedia files } \\
\text { with Hyperstudio } \\
\text { or similar } \\
\text { software }\end{array}$ & $1(1.5 \%)$ & $0.3 \%$ & 0 & 0 & $3(15.0 \%)$ & $3.3 \%$ \\
\hline $\begin{array}{l}\text { Statistical } \\
\text { Software (e.g. } \\
\text { SPSS) }\end{array}$ & $1(1.5 \%)$ & $0.3 \%$ & 0 & 0 & 0 & 0 \\
\hline $\begin{array}{l}\text { Qualitative } \\
\text { software (e.g. } \\
\text { NUDIST) }\end{array}$ & 0 & 0 & 0 & 0 & 0 & c \\
\hline $\begin{array}{l}\text { Using online } \\
\text { educational } \\
\text { systems (e.g. } \\
\text { Blackboard) }\end{array}$ & $6(8.8 \%)$ & $1.2 \%$ & 0 & 0 & $6(30.0 \%)$ & $9.2 \%$ \\
\hline Simulations & 0 & 0 & 0 & 0 & 0 & 0 \\
\hline $\begin{array}{l}\text { Graphics } \\
\text { calculators }\end{array}$ & $1(1.5 \%)$ & $0.3 \%$ & $1(4.8 \%)$ & $2.1 \%$ & 0 & c \\
\hline Other $^{\mathrm{b}}$ & $8(11.9 \%)$ & $3.5 \%$ & $4(19.0 \%)$ & $5.0 \%$ & $2(10.0 \%)$ & $5.0 \%$ \\
\hline
\end{tabular}

Assessment and Evaluation in Higher Education, Vol. 29, No. 5 (2004): pg. 549-561. DOI. This article is (C) Taylor \& Francis (Routledge) and permission has been granted for this version to appear in e-Publications@Marquette. Taylor \& Francis (Routledge) does not grant permission for this article to be further copied/distributed or hosted elsewhere without the express permission from Taylor \& Francis (Routledge). 